\title{
Graffi Murine Leukemia Virus
}

National Cancer Institute

\section{Source}

National Cancer Institute. Graffi Murine Leukemia Virus. NCI Thesaurus. Code C29916.

A nondefective ecotropic retrovirus that was originally reported to induce myeloid

leukemia in some strains of mice; isolated from filtrates of transplantable tumors; a species of gammaretrovirus. 